\title{
Research on the Development Direction of the English Language from the Perspective of Cultural Infiltration and Integration
}

\author{
Xiaomei Wen ${ }^{1}$ \\ ${ }^{1}$ Hubei University of Science and Technology, \\ Xianning City, Hubei Province, 437100
}

\author{
Lijun Wang ${ }^{1, *}$ \\ ${ }^{1}$ Hubei University of Science and Technology, \\ Xianning City, Hubei Province, 437100 \\ Corresponding author
}

\begin{abstract}
In this paper, we conduct research on the development direction of the English language from the perspective of cultural infiltration and integration. In today's world of cultural exchange and dissemination of more and more closely, to move towards the world and the future of English culture and will the extensive and profound English culture show in front of the world and our culture is proposed. Both Britain and America's international standing as the source language country to the popularity of the English is self-evident. Our research is novel and original which will not only enhance the research of the English but help us understand the language better.
\end{abstract}

Keywords: English Language; Cultural Infiltration; Cultural Integration; Literature Review.

\section{Introduction}

Language conforms to the needs of human society, and with the development of human society development. The development and changes of English, he fully demonstrated the rule. Development and changes of English, embodied in many aspects, this paper focuses on the inside of the English language and use scope of the changes and expansion of the American English and the development direction of English problems, a preliminary discussion. Teacher's work is a kind of professional in the past, as long as each subjects knowledge. Today with discipline knowledge alone is not enough, however, will also have to be engaged in education teaching work of specialized knowledge ability and lifelong learning ability, this is in line with the requirements of teaching handsome qualification. So the basic meaning of teachers' specialization is the teachers' work is not only a career, but a professional. Teachers' professional development has become a modern education reform and development direction and theme. People are becoming more and more realized that in economy umbrella and under the background of the rapid development of science and technology, in the economic competition success or failure of key personnel, rely on education and talent cultivation, the development of education by teachers. Only professional constantly improve the level of education can guarantee the high quality level of education, to cultivate high-quality talents [1].

In today's world of cultural exchange and dissemination of more and more closely, to move towards the world and the future of Chinese culture and will the extensive and profound Chinese culture show in front of the world and our culture is proposed. In contrast, has developed into the current English has special function and the status of the real gain global recognition from each country language. This phenomenon is known as the globalization of English. The globalization of English on the one hand, to a large extent for exchange and dialogue between the races of the world or to eliminate the language barrier, has provided people with 
convenient, become the numerous nation or country to get one of the important conditions to develop. Language is the ability to communicate successfully, culture is the foundation of cross-cultural ability. Chinese culture and English culture knowledge are equally important. Test certificate. Chinese and English are the two languages asked huge difference had a certain influence on both the correlation is Chinese ability does the effect of migration on the English language ability. English professional knowledge should include the history of Chinese and English culture learning and research, Chinese and English literature appreciation, China, and both sides of the habits and customs and lifestyle. Unfortunately, at present most of the students' ability in culture appear the phenomenon of one-sided, learn the history of western knowledge blindly, and ignore the importance of local culture. Both Britain and America's international standing as the source language country to the popularity of the English is self-evident and in short, the British colonial hegemony laid the foundation of English globalization. American economic supremacy and the influence of science and technology have given the rise to English language hegemony, under the background of globalization, English language hegemony of the globalization to the climax.

The English language to the rest of the world's best language essence is blended in among them, as well as China's hybrid rice becomes the power of its example. English is derived from the French and inherited the language is elegant, and at the same time as America's racial integration and absorb the Indian language of honest and simple, with the further communication and development of the world and the Chinese language implicit beauty is blended in among them [2-3]. With the development of modern society and culture, English vocabulary is rich, many of the new era vocabulary gradually being created for people to use, and continue to update with the progress of the society, these new words carrying modern culture to meet the use requirements of contemporary people.

In this paper, we conduct research on the development direction of the English language from the perspective of cultural infiltration and integration. Several technological revolutions will not only promoted the emergence and development of modern science and technology, also has big changes on the social each domain. And these changes to its place in the field of cultural innovation has played a certain role in promoting, the causes of these conditions are new words constantly [4-5]. In addition, a variety of modern media is widely used to create the source of these new words come from different social classes and life field, and quickly recognized by people and applications. With the increasingly application of the new words they blended in people's lives, and because of its convenience and interesting, innovative and rooted in the social culture which will be discussed below.

\section{Our Proposed Methodology}

\section{The English Communication and Teaching} Development. China's foreign language education for quite a long time is affected by structuralism and behaviorism and lay particular stress on in language teaching, in the form of cultural education in very low proportion of foreign language teaching. In recent years, as people for language and culture, the understanding of the relationship between culture and communication deepen gradually, people began to sure the indivisibility between language and culture and the importance of cultural factors in intercultural communication. Cross-cultural is compared with the national culture. The differences or conflicts with the national culture of cultural phenomenon are fully correct understanding, and based on this tolerant attitude to accept and adapt. English curriculum standard. Thus it can be seen. Highlight the cultivation of students' autonomous learning ability, is not only beneficial to their development of student's 
learning potential, still can make them improve the level of comprehensive expression skills in practice [6]. Foreign culture and native culture has difference. Need through diverse channels and methods of cognition. Make full use of existing learning resources way to help students broaden the cognitive perspective. In enhancing students' learning initiative and activate their understanding on the basis of exploring the motivation, broaden the way to learn, to lay a good foundation for the students to get rich cultural knowledge.

Cultural learning is not only to understand, more in need of continuous development in the inheritance. Learning culture is under the guidance of development thinking, explore the method of cognition, rich encourage students to obtain more abundant intellectual resources. Around the cultural development can cultivate the students' consciousness of the world at the same time of effective help them deepen the cognitive comprehension. Enhance learning acumen. Focus on cultural learning. Let the students to study in an effective thinking method on the basis of deepening practice, is advantageous to the students take the initiative to accept it. On the one hand, the exotic culture recommended students read more newspapers and magazines, let the students accumulate knowledge of language and culture. On the other hand, more learning resources for students with a sound of non-ferrous, lets the student in features of foreign classic original westerners black humor, its distinctive thinking differences between Chinese and western taste. The different need to identify and compare Chinese and western culture and from the difference between Chinese and western culture in the search for a suitable learning cognitive method, is more advantageous to the student to understand. By comparison, students' awareness of not only forms the profound impression, strengthening comprehensive skills in practice [7-9]. Around the eastern and western cultural differences, guides the student to understand the cause of the cultural development, trend and value significance, on the basis of outstanding achieve mastery through a comprehensive study of each other. To help students improve the purity and accuracy of language use. In the process of teaching, on the one hand, should pay attention to cultivate the students' culture learning into consciousness. Let the students in the process of practice experience enhance cognitive comprehension and promote the internalization of language and cultural knowledge is generated.

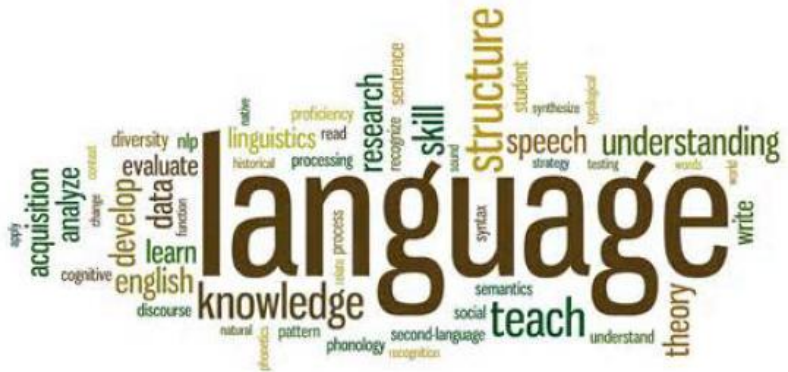

Figure 1. The Department of Linguistics and Language Development

The Development Direction of the English. Language is created by people in the process of labor production, idioms is the concentrated reflection of language features. It comes from the masses of ordinary workers, it is the ordinary people in the productive labor and life experience, is the essence of language, is a microcosm of the language [10]. Language is an arbitrary symbol system, idioms are established in the long-term language practice and labor practice, language is a tool for communication, for the purpose of communication, the origin of idioms are the most frequently used in oral communication of proverb, language is a concentrated manifestation of human wisdom. Idioms focus reflects the language of expression means and rhetoric, language is for the people engaged in all kinds of activities and services, idiom vivid accurately reflects the various aspects of human life. Learning of English idioms can help us master the native language of the real language and understand the hidden behind the language of the rich and interesting cultural information. 
British and American literature is the era of the aesthetic expression of life, is the British people and American people's creative use of the English language. Language is the basic elements of literary works, is the cultural representations to the life experience and literature and implicit thinking on life, value orientation and specific ideology. Read British and American literature, is an important way to understand western culture, can be in contact with the supporting surface of the deep culture, namely the fundamental ideas of western culture, value judgment, westerners often use perspective, and the criticism of these perspectives [11]. At the beginning of the 17th century, when the first English settlers to America, they are faced with unfamiliar natural environment and social environment. In order to adapt to the changed environment, their language must also change. By creating new words, and to give new meanings of old words. Use of native language and the English settlers of the words in language, gradually formed a language and the British both same and different languages, American English. But in pronunciation, spelling, grammar, vocabulary, idioms and so on has its uniqueness, reflects the characteristics of American society and culture. After a long period of development, finally become an independent way in English.

The development direction of English could be summarized as the follows. (1) All national language, each has advantages and disadvantages, all need to constantly improve. In fact, any living language and are constantly updated, in the process of enrichment, all need to absorb the new nutrition. English has become the language of words is very rich, a large number of absorption loan word is undoubtedly one of the important factors. Think only their native language is the most superior, despise other ethnic languages, disdain learning other national language is very harmful. (2) Any an international language. It is in a certain historical condition, English is no exception. Affect the size of a language, and ultimately depends on the use of the language country and national economic and political power. In the international language family, each member's status and relationship is not eternal; International status as a kind of language to use the language of country and the nation's international influence and effect of the change and change. Therefore from its historical position and current situation, as a main international language, English is now and will continue to play an important role in the future but its future depends on various complicated factors in the development of world history. (3) The language of a nation is the nation's spiritual wealth, is one of the focuses of national culture. The international language is necessary is to promote international communication, and with the improvement of cultural education level of the people all over the world, to master the number of international language will be more and more; But, as long as the national coexistence situation continues to exist in the world, any language cannot replace the language, in English or any other kind of language "unified" the language of the world doesn't work.

The Prospect and the Future of English. Progress in the development of modern culture and communication integration to promote the development of English new words constantly update and. Along with the progress of The Times, the English vocabulary will also continuous development to meet the need of cultural expression and demands of the era. In the process of its development, inappropriate ancient words may disappear, the commonly used words will be preserved, and the new or old words new idea will obtain further creation [12]. The emergence of the global village of such cultural fusion result reveals the social and economic exchanges and cooperation, further also highlight the function of the integration of cultural expression. English as the world's first language is not only the world widely used, but also absorbed into this language belong to different culture or race. As is known to all, a variety of cultural function is the most representative in the 
transmission function of the Internet technology tools produce is pushed to the massive spread of the new word and the generation of new words and promotion also cannot leave the two role, especially in the development of globalization today, the role of the Internet to be reckoned with. As a system administrator, podcasts, and big data such new words emerge in endlessly. In addition, reporters and a variety of media such as magazine, newspaper, radio and television and other new ones also have played a role in promoting the development of new and diverse literature makes the language become more abundant vocabulary also accelerated the spread of culture through marketing and promotion of new words. One new word is often used by people often receive such as increasingly update English dictionary, to acknowledge the use of these new words in the social and cultural rationality.

\section{Conclusion}

In this paper, we conduct research on the development direction of the English language from the perspective of cultural infiltration and integration. Any a kind of language learning, not only from books to learn a language and grammar, tenses, but should also include in this kind of language and culture background knowledge acquisition and social customs and habits, etc. Idioms as the essence of language, it from various aspects reflect a nation's history, customs and habits, etc., can say, national color is the most distinct idiom. In addition, the real meaning of the idiom is not the combination of the English vocabulary meaning. If you don't understand the cultural background of the idiom or single interpreted from the English vocabulary, translation which can make us into the erroneous zone. Our research is meaningful for analyzing the development of English.

\section{References}

[1] O'Louglin K. English language standards in higher education: from entry to exit[J]. Higher Education Research \& Development, 2014, 33(2):402-404.

[2] $\mathrm{Xu}$ D. English Language Teaching in East Asia Today: Changing Policies and Practices[J]. Language in Society, 2003, 6(5):86-88.

[3] Uchikoshi Y. Development of vocabulary in Spanish-speaking and Cantonese-speaking English language learners[J]. Applied Psycholinguistics, 2014, 35(1):págs. 119-153.

[4] Song C. Blending and Development of Neo-Confucianism and Scientific Culture in Song Dynasty in Hunan Province from STS Perspective[J]. Journal of Dialectics of Nature, 2014.

[5] Yan, T., Gao, J., Wang, L., Xiangfeng, D. U., \& Wang, R. (2013). Integration and reflection:analysis of sports culture patterns from the perspective of basic elements and structure. Journal of Tianjin University of Sport.

[6] Qiong L I. Cultural Polyphony and Integration_ A Study of The Bonesetter's Daughter from the Perspective of Diaspora[J]. Journal of Changsha University, 2013.

[7] Feng, C. (2013). On cultural value orientation of the chinese communist party from the perspective of value integration. Journal of Hengyang Normal University.

[8] Corporation H P. Anatomo-Functional Correlation between Head Zones and Acupuncture Channels and Points: A Comparative Analysis from the Perspective of Neural Therapy.[J]. Evidence-based complementary and alternative medicine : eCAM, 2014, 2014. 
[9] Boyd M. Medieval Translations and Cultural Discourse: The Movement of Texts in England, France, and Scandinavia by Sif Rikhardsdottir (review)[J]. Arthuriana, 2013, (4):124.

[10]Huddleston R, Pullum G. 2002 The Cambridge Grammar of the English language Cambridge[J]. R Huddleston and, 2002, 87(6):740-751.
[11] Al-Issa A S M. The Cultural and Economic Politics of English Language Teaching in Sultanate of Oman[J]. Asian Efl Journal, 2006, 8(1).

[12]Dewey M, Leung C. English in English Language Teaching: Shifting values and assumptions in changing circumstances[J]. Working Papers in Educational Linguistics, 2010, 25(1). 